\title{
The influence of agri-entrepreneurship courses studied on youth farm entrepreneurial intention: Evidence from Folk Development Colleges in Tanzania
}

\begin{tabular}{|c|c|}
\hline \multicolumn{2}{|c|}{$\begin{array}{l}\text { Authors: } \\
\text { Paschal B. Nade }{ }^{1} \text { (D) } \\
\text { Christian K. Malamsha }{ }^{2} \text { (D) }\end{array}$} \\
\hline \multicolumn{2}{|c|}{$\begin{array}{l}\text { Affiliations: } \\
{ }^{1} \text { Department of Business } \\
\text { Studies and Humanities, } \\
\text { Nelson Mandela African } \\
\text { Institution of Science and } \\
\text { Technology, Arusha, Tanzania }\end{array}$} \\
\hline \multicolumn{2}{|c|}{$\begin{array}{l}{ }^{2} \text { Department of Co-Operative } \\
\text { Studies, Faculty of } \\
\text { Co-Operative and Community } \\
\text { Development, Moshi } \\
\text { Co-Operative University, } \\
\text { Moshi, Tanzania }\end{array}$} \\
\hline \multicolumn{2}{|c|}{$\begin{array}{l}\text { Corresponding author: } \\
\text { Paschal Nade, } \\
\text { pascal.nade@nm-aist.ac.tz }\end{array}$} \\
\hline \multicolumn{2}{|c|}{$\begin{array}{l}\text { Dates: } \\
\text { Received: } 01 \text { Aug. } 2020 \\
\text { Accepted: } 15 \text { Jan. } 2021 \\
\text { Published: } 07 \text { Apr. } 2021\end{array}$} \\
\hline \multicolumn{2}{|c|}{$\begin{array}{l}\text { How to cite this article: } \\
\text { Nade, P.B. \& Malamsha C.K., } \\
\text { 2021, 'The influence of } \\
\text { agri-entrepreneurship } \\
\text { courses studied on youth } \\
\text { farm entrepreneurial } \\
\text { intention: Evidence from Folk } \\
\text { Development Colleges in } \\
\text { Tanzania', South African } \\
\text { Journal of Economic and } \\
\text { Management Sciences 24(1), } \\
\text { a3788. https://doi. } \\
\text { org/10.4102/sajems. } \\
\text { v24i1.3788 }\end{array}$} \\
\hline \multicolumn{2}{|c|}{$\begin{array}{l}\text { Copyright: } \\
\text { (C) 2021. The Authors. } \\
\text { Licensee: AOSIS. This work } \\
\text { is licensed under the } \\
\text { Creative Commons } \\
\text { Attribution License. }\end{array}$} \\
\hline \multicolumn{2}{|l|}{ Read online: } \\
\hline 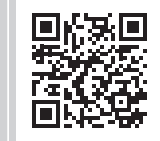 & $\begin{array}{l}\text { Scan this QR } \\
\text { code with your } \\
\text { smart phone or } \\
\text { mobile device } \\
\text { to read online. }\end{array}$ \\
\hline
\end{tabular}

Background: Youth engagement in agriculture in developing countries is of paramount importance since much of their livelihoods depend on this sector.

Aim: This article therefore aims at assessing the influence of studying agri-entrepreneurship courses on youth farm entrepreneurial intention.

Setting: Three of the 55 Folk Development Colleges (FDCs) in Tanzania.

Methods: A cross-sectional design was employed and 300 respondents were randomly selected from three FDCs offering agricultural programmes. Both qualitative and quantitative data were collected and analysed by using descriptive and inferential statistics in which frequencies, percentages, mean, standard deviation and Somers's D Model were employed.

Results: The results show that there is a significant relationship between agri-entrepreneurship knowledge and skills acquired and youth entrepreneurial intentions towards farming.

Conclusion: The FDCs' agri-entrepreneurial training provides knowledge and skills which influence youth farm entrepreneurial intention. However, the strength of this influence ranges from weak to moderate depending on various factors. Regular reviews of curricula to enhance the beliefs that develop a view of farm entrepreneurship as a paying business is recommended. The analysis and implication of this finding has been further explained.

Keywords: agri-entrepreneurship courses; knowledge; skills; farm entrepreneurial intentions; unemployment; the youth.

\section{Introduction}

The effect of agricultural education on increasing productivity and income of farmers has been widely acknowledged by scholars (Anang, Backman \& Sipiläinen 2020; Ashraf \& Qasim 2019; Ferreira et al. 2018; Heanue \& Donoghue 2014). However, agricultural education has not been quick in responding to the needs of the labour market and the changing environment in this era of unprecedented youth unemployment (Alliance for Green Revolution Africa [AGRA] 2015; Sangiga, Lohento \& Mayenga 2015). Currently, the youth unemployment situation remains one of the key global challenges. It is estimated that about 67 million (13.0\%) young people between the ages of 15 and 24 years were unemployed globally in 2018 while in Tanzania youth unemployment stood at $13.4 \%$ against overall $11.7 \%$ unemployment (International Labour Organization [ILO] 2019; National Bureau of Statistics [NBS] 2014).

Education and training have been positively associated with profitability of enterprise and ability to open up opportunities in different sectors and occupations for the youth (Haji 2015; World Bank 2014). Specifically, entrepreneurial education gives more attention to enterprise development and employment generation (Jemal 2017; Wale-Oshinowo \& Kuye 2016). Further studies have recognised that farm entrepreneurship has proved successful in addressing youth unemployment through the establishment of market-oriented and self-owned farm enterprises (D'souza 2013; Hrangao \& Sorokhaiban 2015). In addition, it is noted that an individual with 'farm entrepreneurship' knowledge, skills and behaviours is capable of establishing and developing a profitable farm in a changing business environment (Ruddman 2008; Kahan 2012; Mahendra 2017).

Following the acknowledgement of entrepreneurial education with regard to employment generation, the government of Tanzania allowed entrepreneurship courses to be taught at various 
levels of education as stated in the National Education Policy of 1995. Folk Development Colleges (FDCs) also began teaching entrepreneurship courses in line with the major courses as part of the enforcement of the National Education Policy. In this study the major focus is agriculture; therefore, together with entrepreneurship courses, the researcher coined the term agri-entrepreneurship.

In spite of all this, farming lags behind as the career of choice among agricultural students as noted by Redecker, Wihstutz and Mwinuka (2000) who found that FDC graduates were migrating to nearby towns in search of employment and often did not work in their field of training. Also, Christian (2002) found that FDC graduates were searching for employment in town, despite $55 \%$ of their syllabus being based on practical skills. It is further estimated that only $13 \%$ of lower tertiary technical college (Vocational Education and Training Authority [VETA] and FDC) graduates annually get self-employed in farming (United Republic of Tanzania and International Institute for Educational Planning [URT IIEP] 2011). In addition, Adams, Johanson and Razmara (2013) found that only $39 \%$ of self-employed FDC graduates were partly involved in farming. More recently $\mathrm{Ng}^{\prime}$ atigwa et al. (2020) found that the youth who completed primary school education are more likely to be involved in horticulture agribusiness by about 9.7 times (odds $=9.7$ ) compared with the youth who have a high level of education.

Agricultural graduates' effective entrance into farm entrepreneurship in establishing farm-related enterprises presently is not feasible: parental influence, negative image of the sector and education which are seen as impeding factors for the youth to choose a career in farming (Ezeh \& Juniadu 2019; Heinert \& Roberts 2016). For instance, student pre- and post-attendance tests of agricultural courses show an increase in literacy, but mixed results in terms of attitude and perception toward farm-related enterprises (Kaijage \& Wheeler 2013). Also, as the level of education increases the preference and participation and time devoted to agriculturalrelated enterprises decline. For example, attainment of at least secondary education significantly reduced the probability of participation by $20 \%$ and meant fewer working hours than the uneducated (Afande 2015; Ahaibwe, Mbowa \& Lwanga 2013). This implies that as the youth attain higher education level, they devote their time to non-agricultural activities.

Agricultural education and training have been unresponsive to changing patterns of demands on the youth and seem to lack current skills like opportunity realisation, multi-institutional management capabilities as well as a market-driven system to prepare the youth for entrepreneurship in farming. This is shown by a growing dependence on white-collar jobs in the government and other places which are difficult to come by these days (Agwu, Nwankwo \& Anyanwu 2011; Assane 2015; Sumra \& Katabaro 2014; White 2019). Thus, despite the abundant untapped opportunities in the agricultural sector (Rikken 2015; Rutta 2012), the serious youth unemployment
(ILO 2019), and the agricultural training initiatives for the youth taken by the Government of Tanzania and other stakeholders, the majority of the youth have persistently neglected farm-related enterprises. This study focuses on assessing farm entrepreneurial intention of students majoring in agriculture courses that are blended with an entrepreneurship course.

The study is guided by the Theory of Planned Behaviour (Ajzen 1991), which states that a person's behaviour is a function of their intention, which in turn is a result of attitude, subjective norm and perceived behaviour control. A person's attitude, and subjective and behavioural control are determined by beliefs (Ajzen 1991). The theory fits the study because the youth may gain beliefs about farm entrepreneurship by studying agricultural courses blended with entrepreneurship courses. Therefore, this study is assessing the youth farm entrepreneurial intention by situating agri-entrepreneurship courses in the perceived behavioural control parameter of the theory. In support of the theory, entrepreneurial education has been proven by studies as a key determinant of antecedents (attitude, subjective norms and perceived behavioural control) of entrepreneurial intention; these studies were largely conducted on students majoring in business courses (Dorgan 2015; Li \& Wu 2019; Wale-Oshinowo \& Kuye 2016). Recently scholars have embarked on assessing the entrepreneurial intention of students majoring in other courses such as engineering and agriculture, as presented in the following analysis.

A review of empirical studies that assessed the influence of agri-entrepreneurship courses produces different results as follows: Schlaegel and Koenig (2013) in their review of the dairy sector show that entrepreneurial intentions are central to understanding entrepreneurship as they are the first step in the process of discovering, creating, and exploiting opportunities. Despite the recognition of entrepreneurial intention, some weaknesses of curricula have been pointed out. For instance, Prathima, Kundu and Racine (2008) note that agricultural education and training pedagogy in developing countries essentially remains limited to traditional classrooms (with obsolete theoretical training and the collapse of outreach and extension services). Also, even with the integration of entrepreneurship courses, learning is often limited to cognition, whereas feelings, motives, and personal experiences are neglected (Gemma \& Manipol 2015; Müller 2008).

Liñán, Carlos and Jose (2010) found that the entrepreneurial orientation of individuals, especially the conception of who is an entrepreneur and how to make a venture survive and thrive, influence entrepreneurial intention. They caution the traditional teaching that concentrates only on business plan development skills, whereas they should consider other factors for enterprise start-up. Similarly, Nabi et al. (2018) identified two types of entrepreneurial learning that help in the formation of entrepreneurial intention, which are 
are understanding the entrepreneurial process and understanding the practical skills. If only one type of entrepreneurial learning is administered, the level of intention decreases; for instance, skills alone are not sufficient to give an individual confidence to start a business. Nevertheless, Amani and Kushairi (2017) found higher levels of agribusiness entrepreneurial intention among students with innovativeness and risk-taking characteristics. This indicates that starting a farm enterprise requires a set of skills and competencies that individuals should study by considering the entire enterprise start-up process.

Zakaria, Adam and Abujaja (2014) found that students' perceptions regarding the prospects of agribusiness enterprises have shown a statistically significant influence on students' intentions to take up agribusiness as a future selfemployment avenue. Similarly, Shiri, Alibaygi and Faghiri (2012) revealed that agricultural education contributes to students' entrepreneurial motivations at a moderate to high level. However, the courses of entrepreneurship education alone explain $35.5 \%$ of variances in students' entrepreneurial motivations. Hashemi, Hossein and Rezvanfar (2012) found the existence of entrepreneurial intention among agricultural students with perceived self-efficacy showing stronger significance than college entrepreneurial orientation. Ribeiro, Fernandes and Diniz (2014) found that $35.2 \%$ of the respondents would like to start their own business and contribute to the development of the agriculture sector; however, their findings identified perceived bankruptcy, lack of financial support, and fear of failure as the major difficulties concerning starting a business.

While there is a decline in numbers in youth engagement in farming-related enterprises as level of education, an increase in literacy and technical competencies has been noted in the reviewed studies (Afande 2015; Ahaibwe et al. 2013; Kaijage \& Wheeler 2013). The type of course and content of the course seem to determine farm entrepreneurial intention. However, there are mixed results in terms of farm entrepreneurial intentions as some show more significantly than others. Therefore, this study intended to establish whether indeed agricultural courses blended with entrepreneurship courses indeed influence youths' farm entrepreneurial intentions, with a specific focus on FDCs since they are centred on providing knowledge and skills for self-employment. In this case, intention is the state of mind that directs and guides the actions of the youth toward farm entrepreneurship. It specifically addresses three objectives: firstly, to identify type of knowledge and skills provided by agricultural training institutions in transforming the youth's intention towards farm entrepreneurship. Secondly, to determine the influence of knowledge and skills provided on youth farm entrepreneurial intention.

\section{Methodology The study area}

The study involved three out of 55 FDCs in Tanzania, namely: Mamtukuna (Kilimanjaro Region), Monduli (Arusha Region) and Chisale (Dodoma Region). These FDCs were selected for this study because one of their major objectives of training is to equip the learners with the knowledge and skills that would enable them to be self-employed and self-reliant based on local situations. The three colleges were selected purposively because of the similarity in the nature of the agricultural courses which were blended with an entrepreneurship course. The study population was all finalyear certificate students pursuing agriculture courses.

\section{Study design sampling procedures and sample size}

This study employed a cross-sectional design, which was appropriate for this study because the data were collected from three colleges which are located in three different regions at one point in time. A sample size of 300 students was formed from an estimated population of 1200 from the three colleges using the formula developed by Israel (2013):

$n=N /\left(1+N\left(e^{2}\right)\right)$

[Eqn 1]

In Equation 1, $n$ is the sample size, $N$ population size and $e$ is the level of precision. The formula assumes that $p=0.05$ (maximum variability). The desired confidence level is $95 \%$ and the degree of precision or sampling error accepted is \pm $5 \%$. Therefore $n=1200 /(1+1200(0.05))=300$.

Every element in the sample was selected using simple random sampling, as this procedure considers the sampling elements to have homogenous characteristics (all are final year and their courses are blended with an entrepreneurship course). The sample was drawn from FDCs' admission records and directories. The selection of sample from each institution is shown in Table 1.

\section{Data collection}

The study employed questionnaires, focus group discussions and an interview guide as data collection tools. Pre-testing of questionnaires was done before being administered. The questionnaire forms were distributed to 12 respondents, equivalent to $4 \%$ of the sample size during pre-testing. A few unfamiliar terms were noted, and the researcher made adjustment to those terms by replacing them with more familiar terms. Three hundred questionnaire forms were administered and its development was guided by the Theory of Planned Behaviour as retested by Liñán and Chen (2006). The completed questionnaires forms were 294 (98\%) which were used in the analysis. Six focus groups each consisting of seven students were formed through nomination strategy. Six college staff members (two per college) and two Ministry of Health, Community Development, Gender, Elderly and

TABLE 1: Sample selection by institution.

\begin{tabular}{llcc}
\hline SN & Name of Folk Development College & $\begin{array}{c}\text { Final year } \\
\text { population }\end{array}$ & $\begin{array}{c}\text { Selected } \\
\text { sample size }\end{array}$ \\
\hline 1 & Mamtukuna & 436 & 109 \\
2 & Monduli & 399 & 100 \\
3 & Chisalu & 365 & 91 \\
\hline- & Total & $\mathbf{1 2 0 0}$ & $\mathbf{3 0 0}$ \\
\hline
\end{tabular}


Children (ministry responsible for FDCs) officials were purposively selected and involved in interviews based on their role, knowledge and experience.

The data collected include: respondents' socio-demographic characteristics, types of courses studied, types of teaching methodology applied, existence of intention and expected learning outcomes. Six items that assess the expected learning outcomes (independent variable) were developed from the content of the courses studied and the teaching methods applied. The six items were developed under the guidance of the Damian and Wallace (2015) and Roomi and Redman (2016) studies. The six items were measured by a five-level Likert scale labelled $1=$ strongly disagree to 5 = strongly agree. Likewise, the intention (dependent variable) was assessed by nine items developed under the guidance of Liñán and Chen (2006) and Malebana (2012) and measured on a five-level Likert scale labelled $1=$ strongly disagree to $5=$ strongly agree.

\section{Data processing and analysis}

The data supporting the two objectives of this study were analysed by using descriptive non-parametric inferential statistics and content analysis. Specifically, respondents' socio-demographic characteristics, types of courses studied, types of teaching methodology applied, existence of youth farm entrepreneurial intention and perception of the expected learning outcomes were analysed by using frequencies, percentages, means and standard deviations. The relationship between expected learning outcomes and youth farm entrepreneurial intentions were analysed by using Somers' D non-parametric model.

Somers' $\mathrm{D}$ of $\mathrm{Y}$ with respect to $\mathrm{X}$ is defined as:

$D(Y / X)={ }_{T}(X, Y) /_{T}(X, X)$

In Equation 2, Somers' D coefficient of association for asymmetrical variables, $\mathrm{X}$ is the independent variable pair which include expected learning outcomes assessed by six indicators or items and $\mathrm{Y}$ is the dependent variable pair which is the intention variable assessed by nine indicators or items. If Somers' $\mathrm{D}$ coefficient $>0 \leq+v_{1}$, the variable is regarded to have impact on intention. The choice of Somers' D is based on the central role it plays in rank statistics for non-parametric (Newson 2013). Qualitative information collected from key informants and focused group discussion were conceptually analysed by coding the themes systematically and drawing the key that emerged from them.

\section{Reliability and validity}

Internal reliability of items for the self-administered questionnaire was measured by Cronbach's alpha as defined by Fami (2000):

$$
\alpha=K / K-1 \times S_{T}^{2}-\sum S_{I}^{2}
$$

In Equation 3, $\alpha$ is the alpha coefficient, $K$ is the number of items, $S_{T}^{2}$ is the total variance of the sum of the item and the $S_{I}^{2}$ variance of each individual item. A positive alpha coefficient ranging from 0.7 to 1 was taken into consideration as most recommended internal consistency (Gliem \& Gliem 2003). Pairwise deletion method was applied in performing the reliability analysis. To obtain the required alpha results, some of the items that were in the questionnaire were deleted. Nine items measuring expected learning outcomes were presented to the respondents but three items were deleted after reliability test results with their overall Cronbach's alpha coefficient reading 0.707 . No item was deleted for the entrepreneurial intention item after the reliability test and their respective coefficient read 0.870 .

To ensure that the instrument covered all the components of information, content validity was determined through reviewing previous studies in assessing the adequacy and the accuracy of what it measures. The questionnaire items that measured farm entrepreneurial intention were adopted and modified and fixed to the context from work of Liñan and Chen (2006), Ajzen (1991) and Malebana (2012). The development of topics list, entrepreneurial teaching methodology and expected learning outcomes were guided by the following studies: Damian and Wallace (2015), Gibb and Price (2014), Roomi and Redman (2016), Vesala and Jarkko (2008), Adeyemo (2009), Klein and Bullock (2006) and Vandenbosch (2006).

\section{Findings and discussion Socio-demographic characteristics of respondents}

The analysis of the data shows that the mean age of the respondents was 20.6 years, the lowest being 15 years, and the highest age was 31 years with a standard deviation of 2.439. The average age falls within the age criterion definition of youth by the United Nations. It is also in line with the operational definition of youth used in this study. The distribution by sex shows that women were $11.6 \%$ more than men as shown in Table 2. The respondents involved in the study were in two main groups. The first group was those who specialised in animal husbandry and the second group was those who studied general agriculture (both animal and crops husbandry). The second group did not specialise because they were not sitting for VETA exams which have enrolment limitations as per Form Four National Examination results. In the analysis, the two groups were combined since they are taught using FDC and VETA curricula.

TABLE 2: Socio-demographic characteristics of respondents.

\begin{tabular}{llcr}
\hline Type of variable & Sub-items in the variable & Frequency & $\mathbf{\%}$ \\
\hline Sex & Male & 130 & 44.2 \\
& Female & 164 & 55.8 \\
& Total & 294 & 100.0 \\
\multirow{3}{*}{ Programme pursued } & General agriculture & 73 & 24.8 \\
& Animal husbandry & 221 & 75.2 \\
& Total & 294 & 100.0 \\
\hline
\end{tabular}




\section{Farm entrepreneurial courses studied}

Studies by Assane (2015) and Sumra and Katabaro (2014) have noted mismatched, narrow and outdated agricultural education curricula in developing countries. Following the inadequacy in the curriculum, competencies that focus on preparing the youth to be farm entrepreneurs were assessed. Also, studies by Roomi and Redman (2016), and Vesala and Jarkko (2008) have recommended skills training and attribute development for context-specific entrepreneurship education. Therefore, the competencies and skills assessed in this study have been categorised according to the aspects that guide farm enterprise development or growth (agriculture and general entrepreneurship competencies). The assessment of competencies and skills was conducted in the form of topics studied at this level, as shown in Table 3. The list presented was cross-checked against the existing FDC curriculum.

The findings (Table 3) show that for the agricultural courses, animal husbandry is the most studied topic, followed by crop production; the least studied topic was agro-mechanics, followed by agro-economics. The topics assessed are mostly found in the curriculum of FDCs, except the value addition and value chain. However, content-wise, some topics are taught at a very elementary stage (lower levels of cognitive domain; action verbs such as define and mention) and some important topics are missing. Following the inadequate content in the FDC curriculum, in 2013 the government through the Ministry of Health, Community Development, Gender, Elderly and Children allowed the parallel use of VETA curriculum to supplement the FDC curriculum as explained by the ministry director coordinating Community Development Training Institutes and FDCs:

'We are currently using VETA curriculum to cope with changes in the industry and it allows our students to sit for VETA exams as our curriculum doesn't allow our students to proceed for further studies.' (Participant 16, Ministry Director, 10 February 2016)

This was further confirmed during the interviews with FDC principals and Ministry of Health, Community Development, Gender, Elderly and Children officials.

\begin{tabular}{llc}
\multicolumn{2}{l}{ TABLE 3: Basic farm entrepreneurial competencies studied $(N=294)}$. \\
\hline Type of topic & Yes & $\%$ \\
\hline Animal husbandry & 222 & 75.5 \\
Crop production & 208 & 70.7 \\
Agro-mechanics & 112 & 38.1 \\
Agro-economics & 121 & 41.2 \\
Farm management and planning & 140 & 47.6 \\
Communication, negotiation and problem solving & 242 & 82.3 \\
Business plan development & 226 & 76.9 \\
Financial management & 171 & 58.2 \\
Human resource management & 117 & 39.8 \\
Innovation and opportunity recognition & 183 & 62.2 \\
Theories and process of entrepreneurship & 248 & 84.4 \\
Essentials of enterprise or business ownership & 255 & 86.7 \\
New venture planning, creation and management & 197 & 67.0 \\
Basics of computer and information technology & 241 & 82.0 \\
\hline
\end{tabular}

On the other hand, the review shows that although the entrepreneurship course was not in the FDC curriculum, the students were taught using the VETA curriculum. Students have studied all courses that teach basic entrepreneurship knowledge and skills, except the Human Resource Management course. The Human Resource Management course is not an entrepreneurship course per se but it is important because it helps an entrepreneur to manage their employees properly during the expansion stage of an enterprise. However, it has not been critically adapted to the agricultural context as it lacks a practical facet. General implication of the score is that learners are expected to possess the right entrepreneurship competencies.

Based on these findings, the majority of the respondents have basic agricultural and entrepreneurship competencies that can help them to establish farm enterprise. Although some basic topics such as value addition, value chain and human resource management are missing in both the FDC and VETA curricula, with such competencies, the youth can at least manage to start up an enterprise. This is because the ideal requirement is awareness or exposure and basic applied skills that are enterprise-specific in order to launch an enterprise.

The question of adequacy of syllabus in terms of content was asked to the tutors and the response was that with the introduction of the VETA-curriculum, their syllabus was deemed adequate; when the follow-up question was asked about why the graduates find it difficult to start or establish an enterprise, the Mamtukuna tutors explained:

'The environment [infrastructure, and few qualified tutors] for teaching does not motivate learners to start their own enterprise. The component that deals with motivation or character development also needs to be added into their syllabus.' (Participant 11, Tutor, 21 January 2016)

This also emerged during the focus group discussion as one of the discussants explained:

'There are no laboratories and facilities for conducting experiments, the situation has affected us for example we are not familiar with much of the skills in the topic of anatomy.' (Participant 5, Student, 18 January 2016)

What is taught is one thing but how it is taught to obtain the best outcome in learning is a different matter. In this case, the teaching methods that were used to deliver the agricultural and entrepreneurship competencies to FDC students were assessed as shown in Table 4.

The findings show that six methods of teaching are commonly applied in the FDCs, with lecture, research and guest speakers less common, as shown in Table 4. As far as developing entrepreneurship traits among students is concerned, the last two techniques of research and guest speakers are crucial as noted by Adeyemo (2009). Research techniques help to build innovation, creativity and analytical capabilities, traits that are important for an entrepreneur. 
In addition, inviting successful entrepreneurs helps to develop motivation, networking and the development of a good attitude concerning the field in which they are expected to work. Thus, less regular use of those methods could have affected the learners' entrepreneurial traits.

During focus group discussions, respondents were asked if they are happy with the teaching methods. They were positive about those courses in which the tutors have good experience and provide practical details in their respective subjects. However, they complained that many of practical skills-oriented topics are only theoretically taught. The focus group discussant explained:

'[The] majority of tutors do not have practical skills, they teach us theoretically only, also there are no laboratory equipment and tools that are used in conducting experiments. For example, there is not any surgery equipment.' (Participant 4, Student, 18 January 2016)

The discussion shows that lack of qualified tutors and appropriate infrastructure for student learning are a constraint to the experiential teaching method. The findings concur with Prathima et al. (2008) who noted that training is limited to traditional classrooms.

\section{Perception of the expected learning outcomes in relation to farm entrepreneurship}

The expected learning outcomes in relation to farm entrepreneurship were assessed as shown in Table 5. The findings show that students agreed and strongly agreed with items 1-6 intended to measure the skills, knowledge and any other lesson factors. Students gained farm entrepreneurship knowledge and were satisfied with teaching methodology applied compared to skills-related outcomes as evidenced by scores in Table 5. These findings concur with those of Rammolai (2009) who noted that time was the limiting factor for entrepreneurship studies in Zimbabwe. However, the actual time allotted is 6 months per term which exceeds

TABLE 4: Teaching methods in Folk Development Colleges $(N=294)$.

\begin{tabular}{lcc}
\hline Type of teaching methodology & Yes & $\mathbf{\%}$ \\
\hline Lecture & 78 & 26.5 \\
Learning by doing & 273 & 92.9 \\
Classroom discussion & 274 & 93.2 \\
Guest speaker & 125 & 42.5 \\
First-hand interaction with farm entrepreneurs & 212 & 72.1 \\
Case studies & 218 & 74.2 \\
Research & 139 & 47.3 \\
Peer tutoring & 255 & 86.8 \\
Simulations and role play & 221 & 75.2 \\
\hline
\end{tabular}

university time allotted per semester by 2 months. Moreover, during the interviews with principals of colleges and during the focus group discussions, it was noted that the majority of tutors work part time. This arose during the focus group discussion; for example, one discussant mentioned that:

'We do not get enough time to stay with our tutors, others come and disappear, in one term and within the same course you can have sometimes more than two tutors.' (Participant 7, Student, 18 January 2016)

In general, the respondents have a good perception of the expected learning outcomes measured in relation to farm entrepreneurship. Also, the curriculum used is relevant to the existing environment and industry as no mismatch has been noted at this perception level. However, practical classroom learning is lacking as reported during focus group discussions; this may have implications in terms of a mismatch with industry requirements for farm entrepreneurship. This finding is consistent with Gemma and Manipol (2015) and Prathima et al. (2008) who found much theoretical emphasis in teaching. In addition, the content of the two curricula that are currently used in parallel was reported as sufficient but some of the students who do not sit for VETA exams are still using FDC curricula and implementers are not mandated as per evaluation to use the VETA curriculum. Furthermore, since the FDC curriculum lacks addressing some of the skills and since the objectives of the two curricula are not the same, there is a need to harmonise the use of the two curricula.

An index was developed to determine the overall level of attainment of the expected learning outcomes of the respondents which was then analysed by descriptive statistics as shown in Table 6. Table 6 was developed from Table 5 where the Likert scale consists of six items and five response options with their respective weights - strongly disagree (1), disagree (2), unsure (3), agree (4) and strongly agree (5) - were transformed into three level responses. With regard to respondents' responses, the total minimum score for the six items was 6 , the total neutral or unsure scores for the six items was 18 and total maximum score for the six items was 30. In developing the index, the researcher grouped the strongly disagree and disagree scores and labelled them as 'learning has no impact', unsure was labelled as 'undecided' and agree and strongly agree were grouped as 'learning has impact'.

Generally, the descriptive statistics in Table 6 show that the courses studied have impact. The implication for this finding

TABLE 5: Perception of expected learning outcomes in relation to farm entrepreneurship.

\begin{tabular}{|c|c|c|c|c|c|c|c|}
\hline Number & Expected learning outcomes & $\begin{array}{c}\text { Strongly } \\
\text { disagree (\%) }\end{array}$ & $\begin{array}{c}\text { Disagree } \\
(\%)\end{array}$ & $\begin{array}{c}\text { Unsure } \\
(\%)\end{array}$ & $\begin{array}{c}\text { Agree } \\
(\%)\end{array}$ & $\begin{array}{c}\text { Strongly agree } \\
(\%)\end{array}$ & Total \\
\hline 1 & The courses have exposed me to basic skills required for farm entrepreneurship & 1.4 & 3.4 & 2.7 & 49.3 & 43.2 & 100.0 \\
\hline 2 & The courses have provided me with enough knowledge to be a farm entrepreneur & 1.4 & 5.1 & 9.9 & 47.3 & 36.4 & 100.0 \\
\hline 3 & The assignments have provided me with a good lesson for farm entrepreneurship & 0.3 & 1.0 & 8.2 & 48.0 & 42.5 & 100.0 \\
\hline 4 & The courses have raised my awareness of the link between farming and industries & 4.1 & 7.1 & 12.6 & 47.3 & 28.9 & 100.0 \\
\hline 5 & The courses were very clear & 1.4 & 5.4 & 6.5 & 57.5 & 29.3 & 100.0 \\
\hline 6 & The courses are relevant to what I observed in the field & 3.4 & 4.8 & 15.6 & 37.8 & 38.4 & 100.0 \\
\hline
\end{tabular}


is that the youth who studied agri-entrepreneurship courses believe they possess the basic farm entrepreneurial knowledge and skills in the related affective learning domains. They are aware of the concept of farm entrepreneurship, familiar with enterprise start-up and its management and they believe they possess basic agriculture field skills. This finding concurs with Nabi et al. (2018) who found the type of entrepreneurial learning (basic knowledge about entrepreneurial process and associated skills) influences individual entrepreneurial intention.

\section{Youth farm entrepreneurial intention}

Farm entrepreneurial intention as a key aspect in this study was assessed by nine items measured on a five-point Likert scale (strongly disagree, disagree, unsure, agree and strongly disagree). The determinants for farm entrepreneurship intention that were assessed include readiness, determination, interest and internal drives (internal locus of control), measured by nine items as shown in Table 7. The findings show that the higher ratings of the respondents fall under the agree and strongly agree measurements. There is a small discrepancy between prior intention in relation to item 8 . This implies that after students' enrolment in the college, they received more exposure, skills, knowledge and confidence which led to an increase (scores) in intention to pursue farm entrepreneurship. By considering the eight item scores measuring intention, the agricultural education blended with entrepreneurship course contributes to the increase in farm entrepreneurship intention of the final-year FDC students. This finding is supported by the studies done by Malebana (2012) and Liñán et al. (2010) who found an increase in intention after studying. Also, the scores for prior intention imply that college agriculture education is not the only contributing factor for intention in farm entrepreneurship; there are other factors that are not explained by this study.

An index was developed to determine the overall level of youth farm entrepreneurial intention of the respondents

TABLE 6: Overall level of expected learning outcomes perception.

\begin{tabular}{lcc}
\hline Learning outcomes & Frequency & $\%$ \\
\hline Learning has no impact & 8 & 2.7 \\
Undecided & 5 & 1.7 \\
Learning has impact & 281 & 95.6 \\
\hline Total & $\mathbf{2 9 4}$ & $\mathbf{1 0 0 . 0}$ \\
\hline
\end{tabular}

after exposure to studying agricultural courses. As shown in Table 8 , the Likert scale consists of nine items and five response options: strongly disagree (1), disagree (2), unsure (3), agree (4) and strongly agree (5). With regard to respondents' responses, the total minimum score for the nine items was 9, the total neutral or unsure scores for nine items was 27 and total maximum score for the nine items was 45 . In developing the index, the researcher grouped the strongly disagree and disagree scores and labelled them as 'no intention', unsure was labelled as 'undecided' and agree and strongly agree were grouped as 'presence of intention'. Generally, the descriptive statistics in Table 8 show that the majority of youth have acquired farm entrepreneurial intention.

The relation between farm entrepreneurial intention and expected learning outcome was assessed. Farm entrepreneurship intention was first assessed based on the fact that they have studied the required courses. However, to obtain a direct relation, the learning outcome factors were established and computed against nine factors of farm entrepreneurship intention.

The findings (Table 9) show that, all eight factors measuring farm entrepreneurship intention, excluding factor number 9 , have significant relation for the majority of expected learning outcome determinants. However, the Somers's D coefficient ranges from below 0.02 to above 0.2 indicating very weak to moderately weak strength of relationship. The relationship between youth farm entrepreneurship intention and expected learning outcome was tested at the $5 \%$ level of significance.

The findings further show that six factors measuring farm entrepreneurial intention have a moderate weak significant relationship with the first determinant of the expected learning outcomes. Since the first expected learning outcome determinant focused on the possession of farm entrepreneurial skills, it is clear that the respondents' farm entrepreneurial

TABLE 8: Overall youth farm entrepreneurial intention.

\begin{tabular}{lcc}
\hline Intention & Frequency & $\mathbf{\%}$ \\
\hline No intention & 20 & 6.8 \\
Undecided & 3 & 1.0 \\
Presence of intention & 271 & 92.2 \\
\hline Total & $\mathbf{2 9 4}$ & $\mathbf{1 0 0 . 0}$ \\
\hline
\end{tabular}

TABLE 7: Farm entrepreneurial intention of the respondents $(N=294)$.

\begin{tabular}{|c|c|c|c|c|c|c|c|}
\hline Number & Entrepreneurial intention indicators & $\begin{array}{c}\text { Strongly } \\
\text { disagree (\%) }\end{array}$ & $\begin{array}{c}\text { Disagree } \\
(\%)\end{array}$ & $\begin{array}{c}\text { Unsure } \\
(\%)\end{array}$ & $\begin{array}{c}\text { Agree } \\
(\%)\end{array}$ & $\begin{array}{l}\text { Strongly } \\
\text { agree }(\%)\end{array}$ & Total \\
\hline 1 & I am ready to do anything to be a farm entrepreneur & 1.7 & 5.1 & 5.4 & 38.1 & 49.7 & 100.0 \\
\hline 2 & My professional goal is to be a farm entrepreneur & 2.7 & 6.8 & 5.4 & 28.6 & 56.5 & 100.0 \\
\hline 3 & I will make every effort to start and run my own farm enterprise & 2.4 & 4.4 & 7.1 & 29.3 & 56.8 & 100.0 \\
\hline 4 & I am determined to create a farm enterprise in the future & 0.7 & 4.4 & 9.2 & 37.8 & 48.0 & 100.0 \\
\hline 5 & I do not have doubts about ever starting my own farm enterprise & 0.7 & 5.8 & 11.9 & 37.1 & 44.6 & 100.0 \\
\hline 6 & I have very seriously thought of starting a farm enterprise in the future & 1.0 & 5.1 & 6.8 & 36.4 & 50.3 & 100.0 \\
\hline 7 & I have a strong intention of ever starting a farm enterprise in the future & 2.0 & 3.1 & 6.5 & 35.0 & 53.4 & 100.0 \\
\hline 8 & $\begin{array}{l}\text { My qualification has contributed positively towards my interest in } \\
\text { starting a farm enterprise }\end{array}$ & 1.7 & 3.1 & 3.4 & 41.2 & 50.3 & 100.0 \\
\hline 9 & $\begin{array}{l}\text { I had a strong intention to start my own farm enterprise before } \\
\text { I started my study }\end{array}$ & 5.1 & 13.9 & 5.8 & 37.4 & 37.8 & 100.0 \\
\hline
\end{tabular}


TABLE 9: The relationship between farm entrepreneurial intention and expected learning outcomes.

\begin{tabular}{|c|c|c|c|c|c|c|c|}
\hline \multirow[t]{2}{*}{ Number } & \multirow[t]{2}{*}{ Intention items } & \multicolumn{6}{|c|}{ Expected learning outcomes } \\
\hline & & $\mathrm{O}_{1}$ & $\mathrm{O}_{2}$ & $\mathrm{O}_{3}$ & $\mathrm{O}_{4}$ & $\mathrm{O}_{5}$ & $\mathrm{O}_{6}$ \\
\hline 1 & I am ready to do anything to be a farm entrepreneur & M & W & W & ns & W & Ns \\
\hline 2 & My professional goal is to be a farm entrepreneur & M & W & ns & W & W & W \\
\hline 3 & I will make every effort to start and run my own farm enterprise & w & W & w & W & W & W \\
\hline 4 & I am determined to create a farm enterprise in the future & M & W & w & W & W & W \\
\hline 5 & I do not have doubts about ever starting my own farm enterprise & W & ns & ns & ns & ns & W \\
\hline 6 & I have very seriously thought of starting a farm enterprise in the future & M & ns & W & W & ns & W \\
\hline 7 & I have a strong intention of ever starting a farm enterprise in the future & M & W & w & w & w & w \\
\hline 8 & My qualification has contributed positively towards my interest in starting a farm enterprise & M & W & M & W & W & W \\
\hline 9 & I had a strong intention to start my own farm enterprise before I started my study & W & W & W & W & W & Ns \\
\hline
\end{tabular}

Note: Significant at $5 \%$.

$\mathrm{M}$, moderately weak ( $>0.2) ; \mathrm{W}$, very weak $(<0.2)$; ns, not significant; $\mathrm{O}_{1}$, The courses have me exposed to basic skills required for farm entrepreneurship; $\mathrm{O}_{2}$, The courses have provided me enough knowledge to be a farm entrepreneur; $\mathrm{O}_{3}$, The assignments have provided me a good lesson for farm entrepreneurship; $\mathrm{O}_{4}$, The courses have raised my awareness on link between farming and industries; $\mathrm{O}_{5}$, The courses were very clear; $\mathrm{O6}$, The courses are relevant to what I observed in the field.

intention is influenced by studying agriculture and entrepreneurships courses. Also, significant relationships exist between four factors measuring farm entrepreneurial intention and the remaining five expected learning outcome determinants. The implication is that the respondents have acquired farm entrepreneurial knowledge and behavioural competencies which consequently impacted their farm entrepreneurial intention.

This finding concurs with Emanuel's (2012) and Remeikiene, Startiene and Dumciuviene's (2013) studies which found the existence of a farm entrepreneurial intention after studying agriculture courses blended with entrepreneurship courses. This finding is supported by the Theory of Planned Behaviour which asserts that intention can be changed directly or indirectly by the formation of beliefs resulting from the environment (Ajzen 1991). Beliefs in this case were developed by studying agri-entrepreneurship courses. The impact of the training is manifested through a change in the youth's attitude, perception and perceived behavioural control with regard to farm entrepreneurship career. The sum of these behavioural antecedents subsequently changes the youth farm entrepreneurial intention.

\section{Conclusion and recommendations}

From the findings it can be concluded that the basic courses required for farm entrepreneurship were studied except for a few courses that are largely taught theoretically, with the challenges in the practical aspect (laboratory experiments). On the other hand, there is a significant positive relationship between the agri-entrepreneurship courses studied in the FDCs with the youth's farm entrepreneurial intention. The implication is that the youth's farm entrepreneurship intention for FDCs is associated with the learning acquired. They studied the appropriate content through the respective appropriate teaching methodologies as shown in the findings section. The findings also imply that the youth studying in these colleges clearly understand the start-up process of a farm enterprise and associated concepts. The FDC training has also changed the view of agriculture to a paying business as indicated by willingness to engage in farm entrepreneurship and their judgement regarding the benefits that can be obtained by engaging in farm entrepreneurship.
It is recommended that the curricula need to be reviewed regularly and behavioural, together with skill components, and their respective teaching methodologies need to be given more emphasis in colleges that teach agriculture and entrepreneurship courses. Also, the main goals of establishing FDCs and related colleges need to be revisited from time to time and reformulated if the need arises so as to cope with the contemporary social, economic and technological changes.

\section{Acknowledgements}

My sincere appreciation goes to the editors of this article for their efforts and support in editing the document. These include Mr Boscow Mutambira and Ms Asteria Ngaiza.

\section{Competing interests}

The authors declare that they have no financial or personal relationships that may have inappropriately influenced them in writing this article.

\section{Authors' contributions}

P.B.N. and C.K.M. contributed equally to this article.

\section{Ethical considerations}

This article followed all ethical standards for research without direct contact with human or animal subjects.

\section{Funding information}

This research received no specific grant from any funding agency in the public, commercial, or not-for-profit sectors.

\section{Data availability}

The data are available from the corresponding author, P.B.N., upon reasonable request.

\section{Disclaimer}

The views and opinions expressed in this article are those of the authors and do not necessarily reflect the official policy or position of any affiliated agency of the authors. 


\section{References}

Adams, V., Johanson, K. \& Razmara, S., 2013, Improving skills development in informal sector, World Bank, Washington, DC.

Adeyemo, S.A., 2009, 'Understanding and acquisition of entrepreneurial skills: A pedagogical re-orientation for classroom teacher in science education', Journal of pedagogical re-orientation for classroom
Turkish Science Education 6(3), 57-65.

Afande, F.O., 2015, 'Youth engagement in agriculture in Kenya: Challenges and prospects', Journal of Culture, Society and Development 7(1), 4-19.

Agwu, N.M., Nwankwo, E.E. \& Anyanwu, C.I., 2011, 'Determinants of agricultural labour participation among youths in Abia State', International Journal of Food and Agricultural Economics 2(1), 157-164.

Ahaibwe, G., Mbowa, S. \& Lwanga, M., 2013, Youth engagement in agriculture in Uganda: Challenges and prospects, Research Series no 106, Economic Policy Research Centre, Kampala.

Ajzen, I., 1991, The theory of planned behaviour: Organizational behaviour and human decision processes, University of Massachusetts, Academic Press.

Alliance for a Green Revolution in Africa (AGRA), 2015, Africa agriculture status report: Youth in agriculture in Sub-Saharan Africa, Issue 3, AGRA, Nairobi.

Amani, Z. \& Kushairi, A.R., 2017, 'Agribusiness entrepreneurial intention among generation Y: The role of personality traits', International Journal of Advanced Biotechnology and Research (IJBR) 8(3), 190-196.

Anang, T., Bäckman, S. \& Sipiläinen, T., 2020, 'Adoption and income effects of agricultural extension in northern Ghana', Scientific African 7, e00219, 1-11. agricultural extension in northern Ghana',
$\mathrm{https} / / /$ doi.org/10.1016/j.sciaf.2019.e00219

Ashraf, M. \& Qasim, M., 2019, 'Impact of education on farmers earning: A household survey data analysis', Educational Research 10(1), 200-213.

Assane, I.M., 2015, Agricultural education and skills improvement framework 2015-2025, NEPAD Planning and Coordinating Agency, Malabo.

Christian, H., 2002, In focus programme on skills, knowledge and employability: New evidence from Kenya, Tanzania and Uganda, International Labour Organization, Geneva.

Damian, P. \& Wallace, I., 2015, 'Revision aid: Agricultural science', Agri-Aware, IASTA and Irish Farmers Journal, 1-156.

D'Souza, A., 2013, 'Unorganized sectors: The role of entrepreneur and challenges in selfemployment', International Journal of Scientific Research and Publication 3(6), 1-5.

Emanuel, S.O., 2012, 'Entrepreneurial intention among business and counselling students: Lagos State University', Journal of Education and Practice 3(14), 64-72.

Ezeh, P.C. \& Juniadu, A.S., 2019, 'Determinants of Nigerian youths' choice of career in agriculture', Journal of Business Management \& Accounts Studies 2(1), 1-8.

Fami, H.S., 2000, 'Development of scale to measure the attitude of rural women toward mixed farming', Journal of Humanities 2(5), 25-30.

Ferreira, A. et al., 2018, 'Urban agriculture, a tool towards more resilient urban communities?' Current Opinion in Environmental Science \& Health 5, 93-97. https://doi.org/10.1016/j.coesh.2018.06.004

Gemma, U.R. \& Manipol, N.E.P., 2015, 'Impact of various teaching methodologies on the entrepreneurial awareness and intention of students at the University of the Philippines Los Banos', International Journal of Academic Research in Business and Philippines Los Banos', International Journal of Academic Research in Business
Social Sciences 5(7), 350-362. https://doi.org/10.6007/IJARBSS/v5-i7/1746

Gibb, A. \& Price, A., 2014, A compendium of pedagogies for teaching entrepreneurship, 2nd edn., International Entrepreneurship Educators Programme.

Gliem, S.J.A. \& Gliem, R.R., 2003, 'Calculating, interpreting, and reporting Cronbach's alpha reliability coefficient for Likert-type', in Midwest Research to Practice Conference in Adult, Continuing, and Community Education, Columbus, $\mathrm{OH}, 8-10$ October.

Haji, M., 2015, Youth employment in Tanzania: Taking stock of the evidence and knowledge gaps, International Development Knowledge Centre, Ottawa.

Hashemi, S.M.K., Hossein, S.M. \& Rezvanfar, F., 2012, 'Explaining entrepreneurial intention among agricultural students: Effects of entrepreneurial self-efficacy and intention among agricultural students: Effects of entrepreneurial self-efficacy and
college entrepreneurial orientation', Research Journal of Business Management college entr.

Heanue, K. \& Donoghue, L., 2014, The economic returns to formal agricultural education, Rural Development Program, Agriculture and Food Development Authority, Teagasc.

Heinert, S. \& Robert, G., 2016, Engaging rural youth in entrepreneurship through extra-curriculum systems, University of Florida, Gainesville, FL.

Hrangao, R.R.B. \& Sorokhaiban, R., 2015, 'Enterprising the farmer entrepreneur', International Journal of Social Sciences Invention 4(4), 28-34.

International Labour Organization (ILO), 2019, World employment social outlook, ILO, Geneva.

Israel, D.G., 2013, Determining sample size, University of Florida, Gainesville, FL.

Jemal, G., 2017, 'Entrepreneurial intention among undergraduate agricultural students in Ethiopia', African Journal of Business Management 11(13), 293-303.

Kahan, D., 2012, Entrepreneurship in farming: Farm management extension guide, Food and Agriculture Organization of the United Nations, Rome.

Kaijage, L. \& Wheeler, S., 2013, Supporting entrepreneurship education in East Africa, University of Nairobi, Nairobi.

Klein, P.G. \& Bullock, J.B., 2006, Can entrepreneurship be taught? McQuinn Center for Entrepreneurial Leadership, University of Missouri, Columbia, MO.

Liñán, F., Carlos, J.R. \& Jose, C.R., 2010, 'Factors affecting entrepreneurial intention levels: A role for education', International Entrepreneurship and Management 7(2), 195-218. https://doi.org/10.1007/s11365-010-0154-z
Li, L. \& Wu, D., 2019, 'Entrepreneurial education and students' entrepreneurial intention: Does team cooperation matter?' Journal of Global Entrepreneurship Research 9(35). https://doi.org/10.1186/s40497-019-0157-3

Liñán, F. \& Chen, Y.W., 2006, Testing entrepreneurial intention model, Universitat Autònoma de Barcelona, Bellaterra.

Mahendra, M., 2017, 'The effect of entrepreneurship education on entrepreneuria intention mediated by motivation and attitude among management students', International Education Studies 10(9), 201. https://doi.org/10.5539/ies. v10n9p61

Malebana, M.J., 2012, Entrepreneurial intent of final-year commerce students in the rural provinces of South Africa, Business Management, University of South Africa, Johannesburg.

Müller, S., 2008, Encouraging future entrepreneurs: The effect of entrepreneurship course characteristics on entrepreneurial intention, University of St. Gallen, St. Gallen.

Nabi, G., Walmsley, A., Liñán, F., Akhtar, I. \& Neame, C., 2018, 'Does entrepreneurship education in the first year of higher education develop entrepreneurial intentions? The role of learning and inspiration', Studies in Higher Education 43(3), 452-467. https://doi.org/10.1080/03075079.2016.1177716

National Bureau of Statistics, 2014, Tanzania integrated labour force survey, Ministry of Labour and Employment, Dar es Salaam.

Newson, B.R., 2013, 'Interpretation of Somers' D', The Stata Journal 55(2), 1-25.

Ng'atigwa, A.A., Hepelwa, A., Yami, M. \& Manyong, V.M., 2020, 'Assessment of factors influencing youth involvement in horticulture agribusiness in Tanzania: A case study of Njombe Region', Agriculture 10(7), 287, 1-17. https://doi.org/10.3390/ agriculture10070287

Prathima, J.K., Kundu, R.S. \& Racine, J.L., 2008, Entrepreneurship curriculum project, Report, JIP Grant, Washington, DC.

Rammolai, L.M., 2009, The image of agriculture education in Botswana, Murdoch University, Perth, p. 190.

Redecker, M., Wihstutz, A. \& Mwinuka, J., 2000, Vocational education and training by government in Tanzania: The example of community oriented vocational training in FDCs, Ministry of Education Science and Technology, Dar es Salaam.

Remeikiene, R., Startiene G. \& Dumciuviene, D., 2013, 'Explaining entrepreneurial intention of university students: The role of entrepreneurial education, management, knowledge and learning', in Proceedings of the International Conference, Zadar, Croatia, 19-21 June.

Ribeiro, M.I.B., Fernandes, A.J.G. \& Diniz, F.J.L.S., 2014, 'Entrepreneurial potential of Portuguese agriculture higher education students: A case from the Alto
Trás-Osmontes Region, Portugal', Экономика Региона 2, 213-220. https://doi. Trás-Osmontes Region, Port
org/10.17059/2014-2-20

Rikken, B., 2015, Tanzania horticulture sector outlook: Opportunities and challenges, Ministry of Economic Affairs of the Kingdom of Netherlands, Waginengen.

Roomi, M. \& Redman, G., 2016, 'Entrepreneurship: A kiss of life for UK farming sector', in Oxford Farming Conference, Andersons Centre, London, 5-7 January.

Rudmann, C., 2008, Entrepreneurial skills and their role in enhancing the relative independence of farmers, Institute of Organic Agriculture, Frick.

Rutta, E., 2012, Current and emerging youth policies and initiatives with a special focus and links to agriculture Tanzania (Mainland), Tanzania Youth Environmental Network, Dar es Salaam.

Sangiga, N., Lohento, K. \& Mayenga, D., 2015, Youth in agribusiness within African agricultural transformation agenda, Abdou Diouf International Conference agricultural transformation
Centre, Dakar, 21-23 October.

Schlaegel, C. \& Koenig, M., 2013, 'Determinants of entrepreneurial intent: A metaanalytic test and integration of competing models', Entrepreneurship Theory and Practice 38(2), 291-332. https://doi.org/10.1111/etap.12087

Shiri, N., Alibaygi, A. \& Faghiri, M., 2012, 'Factors affecting entrepreneurial motivation of agricultural students at Razi University', International Journal of Agricultural Management and Development (IJAMAD) 3(3), 175-179.

Sumra, S. \& Katabaro, J., 2014, Declining quality of education: Suggestions for arresting and reversing the trend, ESRF, Dar es Salaam.

United Republic of Tanzania, 1995, The national education policy of 1995, Ministry of Education Science and Technology, Dar es Salaam.

United Republic of Tanzania and International Institute for Educational Planning, 2011, Tanzania: Education sector analysis: Beyond primary education, the quest for balanced and efficient policy choices for human development and economic growth, UNESCO, Dakar.

Vandenbosch, T., 2006, Post-primary agricultural education and training in sub-Saharan Africa: Adapting supply and changing demand, ICRAF, Nairobi.

Vesala, K.M. \& Jarkko, P. (eds.), 2008, Understanding entrepreneurial skills in farm context, Research Institute of Organic Agriculture, Frick.

Wale-Oshinowo, B.A. \& Kuye, O.L., 2016, 'The influence of entrepreneurship education and knowledge on entrepreneurial intention', Nigerian Journal of Management Studies 16(1), 174-190.

White, B., 2019, Rural youth, today and tomorrow: Investing in rural people, International Fund for Agricultural Development, Rome.

World Bank, 2014, Tanzania productive jobs wanted: Country economic memorandum, World Bank Group, Washington, DC.

Zakaria, H., Adam, H. \& Abujaja, A.H., 2014, 'Assessment of agricultural students of university for development studies intention to take up self-employment in agribusiness', International Journal of Information Technology and Business Management 21(1), 53-67. 